\title{
Compulsory Education Teachers' Perceptions of Resources, Extracurricular Activities and Inclusive Pedagogical Training in Spain
}

\author{
Juan José Leiva-Olivencia ${ }^{1, * \mathbb{C}}$, Maria Carmen López-Berlanga ${ }^{2}$, Antonio Miñán Espigares ${ }^{3}$ (D) \\ and Francisco Villegas Lirola ${ }^{2}$ \\ 1 Department of Didactic and Organization in School, University of Malaga, 29010 Málaga, Spain \\ 2 Department of Education, Faculty of Education Sciences, University of Almería, 04120 Almería, Spain; \\ berlanga@ual.es (M.C.L.-B.); fvillega@ual.es (F.V.L.) \\ 3 Department of Didactic and Organization in School, University of Granada, 18071 Granada, Spain; \\ aminan@ugr.es \\ * Correspondence: juanleiva@uma.es
}

check for

updates

Citation: Leiva-Olivencia, J.J.; López-Berlanga, M.C.; Miñán Espigares, A.; Villegas Lirola, F. Compulsory Education Teachers' Perceptions of Resources, Extracurricular Activities and Inclusive Pedagogical Training in Spain. Sustainability 2021, 13, 5171. https://doi.org/10.3390/su13095171

Academic Editor: Wayne Sailor

Received: 11 April 2021

Accepted: 3 May 2021

Published: 6 May 2021

Publisher's Note: MDPI stays neutral with regard to jurisdictional claims in published maps and institutional affiliations.

Copyright: (C) 2021 by the authors. Licensee MDPI, Basel, Switzerland. This article is an open access article distributed under the terms and conditions of the Creative Commons Attribution (CC BY) license (https:/ / creativecommons.org/licenses/by/ $4.0 /)$.

\begin{abstract}
Inclusive education is an issue of great interest and social and pedagogical significance in the quality of the education system. Its impact on the context, reality and training of teachers is a decisive impulse to build an open mind in relation to diversity as a characteristic element of education and today's society. The objective of this study was to explore the perceptions of compulsory education teachers (primary and secondary) about teacher training, resources, and after-school activities in the care of students with specific educational support needs associated with disability in 12 Autonomous Communities of Spain. A survey has been carried out, for which an ad hoc questionnaire was built, involving 2457 docents. A descriptive and inferential analysis has been carried out by means of an average comparison between each issue and the different intrapersonal factors. Specifically, two types of tests have been used, using the SPSS version 25 program for analysis: testing independent samples (Levene test and $t$-test for equal means) and one-way ANOVA according to the type of independent variable considered. Among the results is the need to increase teacher training in inclusive education, the existence of divergences on the material, and spatial resources available for diversity care. Similarly, the relevance of after-school activities was identified as initiatives and spaces for the visibility of diversity and culture of inclusion in schools.
\end{abstract}

Keywords: inclusive education; teacher training; resources and materials; extracurricular activities

\section{Introduction}

Inclusive education is currently undergoing a constant and continuous process of reconceptualization of its own identity as an open, democratic, and functional pedagogical proposal that ensures quality responses to diversity. We agree with [1] in considering that "teachers are the costliest and most important resource in the education system, without whose will, competence and commitment, inclusive education cannot be carried out" (p. 75). Thus, it is important to emphasize that training is based on specific competences and a positive attitude towards inclusion. They also echo the questions posed by [2] related to finding the most appropriate methodology for teachers to acquire a "culture of inclusion" and to learn to know and adapt to the real expectations and needs of learners. In summary, this study states that:

Teachers must be able to create a welcoming classroom and school climate that allows free communication, exchange and cooperation between students and teachers, and to implement teaching methodologies based on mutual knowledge construction and experience (p. 75).

For the design and development of teacher training, both initial and in-service, the starting point should be the definition of what the profile of the inclusive teacher should 
be. In this regard, the European Agency for Development in Special Needs Education identifies four values that should underpin the competences of teachers in an inclusive school [3]:

- Valuing student diversity. Focusing on diversity as a resource for training, and as an opportunity for learning;

- Support for each student. Valuing and supporting the learning of all students;

- Teamwork and collaboration among teaching staff;

- Lifelong personal and professional development.

For their part, [4], in their study of Compulsory Secondary Education, warn us of a starting problem, which consists of the fact that teachers may consider attending to students with specific educational support needs (SEN) as not within their functions, and that it corresponds to professionals specializing in therapy, hearing and language, etc. These authors carried out a case study in order to diagnose what help and training needs teachers have in order to make inclusive education possible, finding that initial pedagogical training was scarce.

Furthermore, although decentralization and diversity of institutional responses are a defining element of the educational response to diversity in the countries of the European Union, it is clear that there is consensus on the development of school policies aimed at promoting the educational inclusion of students with special educational needs (SEN), providing and financing support teachers for their specific attention, complementary staff (monitors aimed at facilitating social integration, sign language interpreters, physiotherapists, speech therapists, etc.), specific materials and equipment, and training aimed at raising awareness and instructing teachers in the design of strategies to cater for students with some type of abilities that require specific educational attention [5,6]. All of this contributes to the establishment of measures for the development of good inclusive practices that are not only positive for students with SEN, but for all students and the educational community as a whole. The commitment to quality education at the present time requires meeting new challenges with the incorporation of formulas that promote education in values $[7,8]$. Sustainability, a culture of peace, digital competences, and global citizenship are other important components in the construction of new, more open, interconnected, global and networked education systems.

The variability of needs and educational responses will be conditioned by the users. Spaces, infrastructure, and didactic resources have a "reactive" character [9]; consequently, it is essential to count on the voices of the students themselves and their families in the decision-making process regarding the construction, provision, and organization of the different resources involved [10,11].

Educational inclusion is linked to a global vision of participation, equity, and positive valuation of diversity in all spheres and dimensions of the social, pedagogical, and community spheres [12-15]. In this sense, extracurricular and complementary activities play a relevant role in the consolidation of a democratic intersubjective construction of school inclusion $[16,17]$. Thus, the participation of all students in these types of activities, regardless of their characteristics, peculiarities, or singularities in conditions of equity, is a fundamental key that makes the culture of diversity and inclusion visible and adds value to educational centers [18].

Democratic improvements and curricular accessibility are not fully assured if there is not full normalization in the incorporation of students with disabilities in complementary and extracurricular activities. This is not, in any case, a minor or accessory element, but rather an opportunity to reaffirm the pedagogical, ethical, and social commitment to educational inclusion in all facets and areas of school life. Within the wide range of activities (musical, plastic, theatrical, physical-sports, scientific and cultural enquiry, etc.), we must emphasize the relevance of the importance of the school's activities, and highlight the relevance of the participation of students with disabilities in sports activities, because their participation contributes to the generation of a fruitful and positive education in values, being a privileged vehicle in terms of awareness, solidarity, and mutual aid [19-23]. 
Moreover, it is a very important didactic tool to be able to combat children's sedentary lifestyles, which is a very negative aspect in childhood.

In the configuration of these types of activities, families play a decisive role in the search for inclusive alliances that strengthen the institutional commitment of schools to inclusion [24,25]. Inclusion is not a static state or situation, but a path that is undertaken with evidence and determination by re-evaluating the personal and community learning needs of all students, especially the most vulnerable students who require more structures and dynamics of mutual help, cooperation, and solidarity [26]. At this point, it is pertinent to emphasize that "special supports are so necessary for people with disabilities in the education system that they should not be affected by criteria related to the management of spaces, or the rationalisation of resources in an arbitrary manner" [27].

It is not only essential to introduce modern didactic strategies open to educational inclusion in instrumental subjects, but in all curricular areas, which implies a holistic pedagogical perspective for the acquisition of all competences. Among them, we cannot ignore those linked to the arts, physical education, and music education, among others.

The challenge is to promote an education-action of solidarity that promotes the participation of students without any kind of exception. A change of attitude, mentality, and adaptation of teachers is required for the development of inclusion and training in professional competences for the pursuit of quality education. This requires a constant reinforcement of skills, to research, to update, to be dynamic, creative, and open to change [26,28].

The aim of this study was to find out the perceptions of compulsory education teachers about certain didactic and organizational factors for the development of attention to diversity and educational inclusion with students with SEN:

- To find out the teachers' perspective on their professional competence and training needs;

- To investigate certain variables related to the spatial organization, suitability, and sufficiency of personal resources, as well as the materials used;

- To identify teachers' conceptions about the suitability and participation of students with SEN in complementary and extracurricular activities.

\section{Materials and Methods}

This study is part of a broader research project entitled "Evaluation of the response to students with Specific Educational Support Needs associated with disability in Compulsory Education: Current situation and proposal for improvement" (EDU2016-75574-P), in which we aimed to study the pedagogical responses to diversity in compulsory education stages.

\subsection{Design}

This was a cross-sectional, quasi-experimental study in which an ad hoc questionnaire has been developed, for which an analysis of the internal consistency of the instrument has been carried out using Cronbach's alpha test. A purposive sample was selected from the framework of all primary and secondary schools in different Autonomous Communities, both public and private. The aim was to be as representative as possible in terms of the profile and experience of teachers with students with SEN.

Regarding the results of the questionnaires completed, a descriptive analysis was carried out, as well as an inferential analysis by means of a comparison of means between each question and the different intrapersonal factors (see Table 1). Independent samples test analysis was carried out (Levene's test and $t$-test for equality of means) and one-way ANOVA according to the type of independent variable considered. 
Table 1. Statistical tests used by factor.

\begin{tabular}{cllc}
\hline \multicolumn{1}{c}{ Tests Used } & \multicolumn{1}{c}{ Factors } & Comparisons of Averages \\
\hline \multirow{3}{*}{ Independent sample test } & - & Gender & $\begin{array}{c}\text { Two groups (male/female; } \\
\text { rural/urban; } \\
\text { public/concerted) }\end{array}$ \\
& - & Centre ownership & \\
ANOVA unidirectional & - & Age & \\
& - & Experience & Morperience of pupils \\
& & with SEN & \\
& & Autonomous & \\
& & Communities & \\
\hline
\end{tabular}

\subsection{Participants}

This was a study aimed at teachers working in educational centers in the different Autonomous Communities (AA.CC.). A total of 2457 teachers took part. Specifically, 818 were male teachers $(33.3 \%)$ and 1639 were female teachers $(66.7 \%)$. Most of the informants were aged between 31 and 60 years old ( $90 \%$ of the participants), with a distribution of around $30 \%$ for each of the groups aged 31 to 40 years old $(29.5 \%), 41$ to 50 years old $(30.4 \%)$ and 51 to 60 years old $(30.2 \%)$.

In terms of teaching experience, 2106 teachers had between 11 and 40 years of teaching experience $(85.7 \%)$. In terms of experience with students with special educational needs, it is worth noting that $734(29.9 \%)$ had between 0 and 5 years of experience, and the rest (1723 teachers) had 6 or more years $(70.1 \%)$.

Regarding the distribution by Autonomous Communities, teachers were from Andalusia (282), Asturias (55), Aragon (261), Balearic Islands (95), Castile and Leon (284), Catalonia (370), Madrid (291), Castile-La Mancha (174), Galicia (67), Valencian Community (132), Region of Murcia (138), and Extremadura (308). Two thirds of teachers worked in public schools (67\%) and in urban settings (67.1\%).

\subsection{Data Collection Instrument}

In order to collect information, a multidimensional questionnaire was designed, with a total of sixteen questions referring to teacher training (questions 20, 21, 22 and 23), educational guidance $(24,25,26,27)$, material and personal resources $(29,30,31$ and 32$)$, and extracurricular and complementary activities (33, 34, 35 and 36).

From the reliability analysis of the questions for each of the dimensions under study (see Table 2), it can be seen that the Cronbach's alpha test result was above 0.8 in all cases $(0.816$ for teacher training, 0.811 for material and personal resources, and 0.896 for extracurricular and complementary activities).

The different questions were scored by the participants on a Likert scale, with five options ordered from least to most (with least indicating greater mismatch, insufficient fit, etc., and most indicating greater fit). Given the homogeneity of the response typology, it is possible to evaluate the absolute frequencies obtained for each of the response options.

\subsection{Analysis Procedure}

The opinions of teachers regarding the educational response to students with SEN were explored in terms of four dimensions: (a) teacher training; (b) educational guidance; (c) material and personal resources; and (d) extracurricular and complementary activities.

Seven analysis factors were identified to characterize the informants: (1) gender; (2) age; (3) teaching experience; (4) experience with students with SEN; (5) autonomous communities; (6) location of the center (rural/urban); and (7) ownership of the center (public/private). Descriptive analyses of the values attributed to each question for each of the referenced factors (mean, standard deviation, and percentage analysis) were also carried out, as well as inferential analyses by means of a comparison analysis of the 
means of the different factors (dependent variable) in relation to each of the questions asked (independent variable), in order to decide whether it as possible to accept the null hypothesis or equality of means (H0) or the alternative hypothesis (H1). The SPSS v.25 application [29] was used for this purpose. Specifically, in the case of factors (independent variable) with two options (e.g., gender, rural/urban or school ownership), we used Levene's test and $t$-tests for equality of means, and in the case of a greater number of options we used one-way ANOVA (age, experience, experience with students with SEN and autonomous communities).

Table 2. Cronbach's $\alpha$ reliability analysis by variable.

\begin{tabular}{|c|c|c|}
\hline Variable & Items & Cronbach's $\alpha$ \\
\hline Training & $\begin{array}{l}\text { 20. How would you rate your training with regard to responding to diversity in the } \\
\text { classroom (insufficient-sufficient)? } \\
\text { 21. Teacher training related to pupils with SEN associated with disabilities attending the } \\
\text { school is (insufficient-sufficient). } \\
\text { 22. To what extent do teachers share their knowledge and experience in addressing the } \\
\text { needs of students with SEN associated with disabilities (insufficient-sufficient). } \\
\text { 23. In general, the training offer received by the teaching staff in relation to attention to } \\
\text { diversity is (insufficient-sufficient). }\end{array}$ & 0.816 \\
\hline Educational Guidance and Referrals & $\begin{array}{l}\text { 24. The main objective of educational guidance is to help improve student learning } \\
\text { (disagree-agree). } \\
\text { 25. Coordination meetings between the guidance team and the teaching staff favor } \\
\text { reflection on the response to pupils with SEN associated with disability } \\
\text { (disagreement-agreement). } \\
\text { 26. Pupils with SEN associated with disability have clear references to whom they can } \\
\text { turn when faced with a difficulty/need (they do not exist, or they do not turn to } \\
\text { them-they exist, and they turn to them). } \\
\text { 27. Psycho-pedagogical support is used to reduce barriers to learning (never-always). }\end{array}$ & 0.750 \\
\hline Resources & $\begin{array}{l}\text { 29. Classrooms and facilities for students with disabilities are adequately located in the } \\
\text { school (insufficient-sufficient). } \\
\text { 30. Classrooms and facilities for disabled students are adequately adapted (poorly } \\
\text { adapted-perfectly adapted). } \\
\text { 31. Classrooms, where support staff work, are sufficiently resourced } \\
\text { (under-resourced-sufficiently resourced). } \\
\text { 32. The spatial organization of the school makes it possible to meet the needs of students } \\
\text { with disabilities (hinders-facilitates). }\end{array}$ & 0.811 \\
\hline $\begin{array}{c}\text { Extracurricular and } \\
\text { complementary activities }\end{array}$ & $\begin{array}{l}\text { 33. The complementary activities organized by the center allow the participation of all } \\
\text { pupils equally, including pupils with SEN associated with disability (none-full). } \\
\text { 34. The activities (complementary and/or extracurricular) offered by the center are } \\
\text { adapted to the needs of pupils with SEN associated with disability (none-completely). } \\
\text { 35. From the center, students with disabilities are encouraged to participate in the } \\
\text { extracurricular and complementary activities proposed (never-always). } \\
\text { 36. How would you rate the participation of pupils with SEN associated with disability } \\
\text { in the extracurricular activities organized by the school (null-important)? }\end{array}$ & 0.896 \\
\hline
\end{tabular}

\section{Results}

\subsection{Descriptive Analysis}

The most outstanding of the results obtained in the dimension of teacher training (see Table 3) is found in the column of item 23, with the lowest result: $28.6 \%$ at level 2, very close to insufficient. Although the percentage at level 3 is $28.3 \%$, we consider that the training offer received by teachers in relation to attention to diversity is almost insufficient and needs to be increased. Secondly, the teachers' assessment of their training is somewhat higher in the case of their training to respond to diversity (item 20): $38.1 \%$ at level 4 , than their assessment of disability (item 21): $36.6 \%$ at level 3 . This average level on the scale is not very low, but it does lead us to think that it is necessary to increase training in the care of people with disabilities. 
Table 3. Analysis of the frequencies of the teacher training dimension.

\begin{tabular}{|c|c|c|c|c|c|c|}
\hline & $\begin{array}{c}1 \\
\text { (Little) }\end{array}$ & 2 & 3 & 4 & $\begin{array}{c}5 \\
\text { (A Lot of) }\end{array}$ & Total \\
\hline $\begin{array}{l}\text { 20. How would you rate your training with regard to } \\
\text { responding to diversity in the classroom? }\end{array}$ & $4.2 \%$ & $15.6 \%$ & $28.6 \%$ & $38.1 \%$ & $13.2 \%$ & $99.8 \%$ \\
\hline $\begin{array}{l}\text { 21. The training of teachers related to students with SEN } \\
\text { associated with disability attending the center is. }\end{array}$ & $8.9 \%$ & $20.0 \%$ & $36.6 \%$ & $25.4 \%$ & $8.7 \%$ & $99.6 \%$ \\
\hline $\begin{array}{l}\text { 22. To what extent do teachers share their knowledge and } \\
\text { experience in addressing the needs of students with SEN } \\
\text { associated with disabilities? }\end{array}$ & $4.6 \%$ & $15.0 \%$ & $28.5 \%$ & $36.1 \%$ & $15.5 \%$ & $99.7 \%$ \\
\hline $\begin{array}{l}\text { 23. In general, the training offers received by teachers in } \\
\text { relation to attention to diversity are as follows. }\end{array}$ & $15.3 \%$ & $28.6 \%$ & $28.3 \%$ & $22.6 \%$ & $4.8 \%$ & $99.6 \%$ \\
\hline
\end{tabular}

$\%$ Teacher training.

In order for inclusion to evolve positively, it is very necessary for teachers to share their experience and knowledge, which can be used by other students for whom this experience and knowledge is useful, especially in the case of disability. In this case, item 22 attained a percentage of $36.1 \%$ at level 4 , which is very close to maximum satisfaction. Therefore, although higher levels of satisfaction should always be demanded, the result obtained reflects that knowledge and experiences are indeed shared at a good level.

Regarding the psycho-pedagogical guidance dimension (see Table 4), the highest score was obtained in item 24 (39\% at level 5), reflecting the fact that the main objective of guidance is well understood by teachers, and that all the actions taken by guidance are aimed, as well as all the actions of other professionals and parents, at improving student learning.

Table 4. Analysis of the frequencies of the psycho-pedagogical guidance dimension.

\begin{tabular}{|c|c|c|c|c|c|c|}
\hline & $\begin{array}{c}1 \\
\text { (Little) }\end{array}$ & 2 & 3 & 4 & $\begin{array}{c}5 \\
\text { (A Lot of) }\end{array}$ & Total \\
\hline $\begin{array}{l}\text { 24. The main objective of educational guidance is to help } \\
\text { improve student learning. }\end{array}$ & $1.3 \%$ & $4.2 \%$ & $19.5 \%$ & $35.9 \%$ & $39.0 \%$ & $99.8 \%$ \\
\hline $\begin{array}{l}\text { 25. Coordination meetings between the guidance team and } \\
\text { the teaching staff favor reflection on the response to students } \\
\text { with SEN associated with disabilities. }\end{array}$ & $0.9 \%$ & $9.4 \%$ & $21.1 \%$ & $37.7 \%$ & $30.6 \%$ & $99.7 \%$ \\
\hline $\begin{array}{l}\text { 26. Pupils with SEN associated with disability have clear } \\
\text { references to whom they can turn when faced with a } \\
\text { difficulty/need. }\end{array}$ & $1.1 \%$ & $7.4 \%$ & $19.2 \%$ & $41.8 \%$ & $30.3 \%$ & $99.7 \%$ \\
\hline $\begin{array}{l}\text { 27. Educational psychology support is used to reduce barriers } \\
\text { to learning. }\end{array}$ & $0.7 \%$ & $7.5 \%$ & $20.1 \%$ & $42.8 \%$ & $28.6 \%$ & $99.7 \%$ \\
\hline
\end{tabular}

$\%$ Educational orientation.

The remaining items on educational guidance were very high. Three items $(25,26$ and 27) obtained the highest scores at level 4 (37.7\%, $41.8 \%$ and $42.8 \%$, respectively), however it should also be emphasized that the values appearing at level 5 were very high, at around $30 \%$. This indicates that the results obtained in these items are very positive. These refer, in the first place (item 25) to the coordination meetings with the teaching staff, which were very appropriate to help in the response to the care of students with disabilities. Secondly, students had clear points of reference to turn to when they need help (item 26). Thirdly (item 27), educational psychology support was used to reduce barriers to learning.

With respect to the dimension of resources, the results showed that the classrooms where the persons responsible for support worked were half-equipped with the resources they need (item 31). The percentage obtained in level 3 was $31.7 \%$, and in level 4 it was $30.7 \%$. It can be said that classrooms were well resourced (see Table 5). Moreover, the existing teaching resources were well-adapted to the needs of learners with SEN (item 28), with $41.8 \%$ at level 4 . In relation to item 29 , the classrooms and facilities for disabled pupils 
were suitably located in the school, obtaining 34.4\% at level 4, although level 3 had 30.7\%, therefore it is worth pointing out that this aspect could be improved. In the case of item 30, classrooms should also improve in terms of adaptation for students with SEN, because the result reflects $34.6 \%$ at level 3 .

Table 5. Analysis of the frequencies of the resources dimension.

\begin{tabular}{|c|c|c|c|c|c|c|}
\hline & $\begin{array}{c}1 \\
\text { (Little) }\end{array}$ & 2 & 3 & 4 & $\begin{array}{c}5 \\
\text { (A Lot of) }\end{array}$ & Total \\
\hline $\begin{array}{l}\text { 28. The teaching resources used are adapted to the needs of } \\
\text { students with SEN. }\end{array}$ & $1.7 \%$ & $8.3 \%$ & $31.8 \%$ & $41.8 \%$ & $16.1 \%$ & $99.7 \%$ \\
\hline $\begin{array}{l}\text { 29. Classrooms and facilities for students with disabilities are } \\
\text { conveniently located in the school. }\end{array}$ & $4.3 \%$ & $17.0 \%$ & $30.7 \%$ & $34.4 \%$ & $12.9 \%$ & $99.4 \%$ \\
\hline $\begin{array}{l}\text { 30. Classrooms and facilities for disabled students are } \\
\text { suitably adapted. }\end{array}$ & $6.3 \%$ & $14.0 \%$ & $34.6 \%$ & $31.7 \%$ & $13.0 \%$ & $99.7 \%$ \\
\hline $\begin{array}{l}\text { 31. The classrooms where support workers work have } \\
\text { sufficient resources. }\end{array}$ & $7.8 \%$ & $20.1 \%$ & $31.7 \%$ & $30.7 \%$ & $9.2 \%$ & $99.5 \%$ \\
\hline $\begin{array}{l}\text { 32. The spatial organization of the school makes it possible to } \\
\text { meet the needs of students with disabilities. }\end{array}$ & $5.2 \%$ & $14.9 \%$ & $33.6 \%$ & $33.1 \%$ & $12.8 \%$ & $99.6 \%$ \\
\hline
\end{tabular}

$\%$ Resources for the care of students with SEN.

The spatial organization of the school needs to be improved in order to meet the needs of students with disabilities. Thus, the result obtained in item 32 was 33.6\% at level 3 .

The dimension of extracurricular and complementary activities (see Table 6) reflected, specifically in item 33, that it was suitable, having the highest percentage, $32.2 \%$ in level 5; therefore, we can say that students with disabilities could participate in the center's complementary activities. Not only are they allowed to participate, but they are also encouraged to take part in extracurricular and complementary activities. The result obtained in item 35 was $38.9 \%$ at level 5 .

Table 6. Analysis of the frequencies of the extracurricular and complementary activities dimension.

\begin{tabular}{|c|c|c|c|c|c|c|}
\hline & $\begin{array}{c}1 \\
\text { (Little) }\end{array}$ & 2 & 3 & 4 & $\begin{array}{c}5 \\
\text { (A Lot of) }\end{array}$ & Total \\
\hline $\begin{array}{l}\text { 33. The complementary activities organized by the center } \\
\text { allow the participation of all pupils equally, including } \\
\text { therefore pupils with SEN associated with disabilities. }\end{array}$ & $3.0 \%$ & $11.6 \%$ & $21.9 \%$ & $30.8 \%$ & $32.2 \%$ & $99.6 \%$ \\
\hline $\begin{array}{l}\text { 34. The activities (complementary and/or extracurricular) } \\
\text { offered by the center are adapted to the needs of pupils } \\
\text { with disabilities. }\end{array}$ & $4.2 \%$ & $17.3 \%$ & $26.9 \%$ & $31.6 \%$ & $19.6 \%$ & $99.6 \%$ \\
\hline $\begin{array}{l}\text { 35. The center encourages students with disabilities to take } \\
\text { part in the extracurricular and complementary } \\
\text { activities proposed. }\end{array}$ & $2.6 \%$ & $10.3 \%$ & $18.4 \%$ & $29.4 \%$ & $38.9 \%$ & $99.6 \%$ \\
\hline $\begin{array}{l}\text { 36. How would you rate the participation of pupils with SEN } \\
\text { associated with disability in the extracurricular activities } \\
\text { organized by the school? }\end{array}$ & $4.4 \%$ & $16.9 \%$ & $27.4 \%$ & $28.1 \%$ & $22.6 \%$ & $99.5 \%$ \\
\hline
\end{tabular}

\footnotetext{
$\%$ Extracurricular and complementary activities.
}

Regarding the adaptation of these activities to people with disabilities (item 34), although the result was positive- $31.6 \%$ in level 4 -it is possible to deduce that it needs improvement, because level 3 was in second place with a high percentage $(26.9 \%)$. Although students with disabilities are allowed and encouraged to participate in extracurricular and complementary activities, the teachers' assessment was somewhat lower, remaining at level 4 with $28.1 \%$, and $27.4 \%$ at level 3 , thus an intermediate range of assessment predominated.

Regarding the teacher training dimension (items 20 to 23), we highlight that items 20, 21 and 22 were slightly above the average-3.40, 3.05, and 3.43, respectively (Table 7)however, the average for item 23 was slightly below average (2.73). This means that the teachers' assessment of their training in diversity and attention to learners with SEN was 
average, neither satisfactory nor unsatisfactory, as was the case with the item referring to sharing knowledge and experiences. However, the score for item 23, which refers to the educational offer received at the school, was lower and clearly insufficient. In the dimension referring to psycho-pedagogical guidance (items 24 to 27), the average score was close to 4 out of 5 , and even item 24 scored 4.07 on average. As can be seen, there were positive perceptions of guidance.

Table 7. Descriptive statistics for scores on items 20 to 36.

\begin{tabular}{ccccc}
\hline Items & Media & \multicolumn{3}{c}{ Deviation } \\
\hline 20 & 3.40 & \multicolumn{2}{c}{1.036} \\
21 & 3.05 & 3.43 & 1.077 \\
22 & & 2.73 & 1.066 \\
23 & & 4.07 & 1.117 \\
24 & & 3.88 & 0.928 \\
25 & & 3.93 & 0.982 \\
26 & & 3.91 & 0.941 \\
27 & & 3.63 & 0.921 \\
28 & & 3.35 & 0.908 \\
29 & & 3.31 & 1.044 \\
30 & & 3.14 & 1.067 \\
31 & & 3.34 & 1.085 \\
32 & & 3.78 & 1.045 \\
33 & & 3.45 & 1.111 \\
34 & & 3.92 & 1.115 \\
36 & & 3.48 & 1.104 \\
& & & 1.146 \\
\hline
\end{tabular}

Resources, which included questions on teaching resources and the suitability of the classrooms where students are taught (items 28 to 32), were closer to the value of 3 , with an average mean of 3.3, which means that this is a dimension in need of improvement.

Regarding extracurricular and complementary activities, the averages obtained were around 3.7. This average is very close to 4 , which is a good score. However, there are some aspects that need further improvement, such as items 34 and 36, which had the lowest scores. They refer to the adaptation of these activities (item 34, mean: 3.45) and the teachers' assessment of the participation of students with disabilities in these activities (item 36, mean: 3.48).

\subsection{Inferential Analysis}

A comparative analysis of the different factors in relation to each of the questions was carried out in order to decide whether it was possible to accept the null hypothesis or the hypothesis of equality of means (H0), or the alternative hypothesis (H1) (Table 8).

The most significant results in relation to the age factor are as follows: in the items related to teacher training $(20,21,22$ and 23$)$ there were significant differences; in the items related to resources (24 to 32 ) there were also significant differences, except in items 27 , 29 and 32; in the dimension on activities (33, 34, 35 and 36), there were no significant differences. We can highlight that for question 24 , the youngest (20-30 years old) and oldest (61-68) teachers are the ones who highlight the help provided by the guidance team in helping students with SEN to learn.

In relation to teaching experience, we found significant differences in items $24,29,30$ and 31. The rest of the items in this dimension did not offer significant differences.

Regarding professional experience in teaching students with SEN associated with disability, the results showed that there were significant differences, except in items 24 and 32.

Concerning the Autonomous Communities, in the dimension of teacher training, we note that there were significant differences in items 21, 22 and 23, and not in item 20, where 
there were no significant differences. In terms of resources, there were differences in items $26,27,29$ and 31 . The questions on activity dimension did show significant differences.

Table 8. Inferential analysis (ANOVA) of the items of the 4 dimensions.

\begin{tabular}{|c|c|c|c|c|c|c|c|c|}
\hline Items & Age & & Exper. & & Ex s.e.n. & & AACC & \\
\hline 20 & 0.001 & $\mathrm{H}_{1}$ & 0.180 & $\mathrm{H}_{0}$ & 0.000 & $\mathrm{H}_{1}$ & 0.246 & $\mathrm{H}_{0}$ \\
\hline 21 & 0.001 & $\mathrm{H}_{1}$ & 0.177 & $\mathrm{H}_{0}$ & 0.001 & $\mathrm{H}_{1}$ & 0.000 & $\mathrm{H}_{1}$ \\
\hline 22 & 0.009 & $\mathrm{H}_{1}$ & 0.128 & $\mathrm{H}_{0}$ & 0.000 & $\mathrm{H}_{1}$ & 0.000 & $\mathrm{H}_{1}$ \\
\hline 23 & 0.030 & $\mathrm{H}_{1}$ & 0.095 & $\mathrm{H}_{0}$ & 0.000 & $\mathrm{H}_{1}$ & 0.000 & $\mathrm{H}_{1}$ \\
\hline 24 & 0.042 & $\mathrm{H}_{1}$ & 0.029 & $\mathrm{H}_{1}$ & 0.650 & $\mathrm{H}_{0}$ & 0.071 & $\mathrm{H}_{0}$ \\
\hline 25 & 0.030 & $\mathrm{H}_{1}$ & 0.055 & $\mathrm{H}_{0}$ & 0.001 & $\mathrm{H}_{1}$ & 0.885 & $\mathrm{H}_{0}$ \\
\hline 26 & 0.001 & $\mathrm{H}_{1}$ & 0.463 & $\mathrm{H}_{0}$ & 0.000 & $\mathrm{H}_{1}$ & 0.005 & $\mathrm{H}_{1}$ \\
\hline 27 & 0.192 & $\mathrm{H}_{0}$ & 0.253 & $\mathrm{H}_{0}$ & 0.034 & $\mathrm{H}_{1}$ & 0.002 & $\mathrm{H}_{1}$ \\
\hline 28 & 0.023 & $\mathrm{H}_{1}$ & 0.310 & $\mathrm{H}_{0}$ & 0.000 & $\mathrm{H}_{1}$ & 0.531 & $\mathrm{H}_{0}$ \\
\hline 29 & 0.254 & $\mathrm{H}_{0}$ & 0.018 & $\mathrm{H}_{1}$ & 0.003 & $\mathrm{H}_{1}$ & 0.000 & $\mathrm{H}_{1}$ \\
\hline 30 & 0.006 & $\mathrm{H}_{1}$ & 0.009 & $\mathrm{H}_{1}$ & 0.001 & $\mathrm{H}_{1}$ & 0.334 & $\mathrm{H}_{0}$ \\
\hline 31 & 0.035 & $\mathrm{H}_{1}$ & 0.038 & $\mathrm{H}_{1}$ & 0.000 & $\mathrm{H}_{1}$ & 0.005 & $\mathrm{H}_{1}$ \\
\hline 32 & 0.072 & $\mathrm{H}_{0}$ & 0.237 & $\mathrm{H}_{0}$ & 0.054 & $\mathrm{H}_{0}$ & 0.078 & $\mathrm{H}_{0}$ \\
\hline 33 & 0.942 & $\mathrm{H}_{0}$ & 0.007 & $\mathrm{H}_{1}$ & 0.013 & $\mathrm{H}_{1}$ & 0.000 & $\mathrm{H}_{1}$ \\
\hline 34 & 0.840 & $\mathrm{H}_{0}$ & 0.003 & $\mathrm{H}_{1}$ & 0.000 & $\mathrm{H}_{1}$ & 0.000 & $\mathrm{H}_{1}$ \\
\hline 35 & 0.074 & $\mathrm{H}_{0}$ & 0.062 & $\mathrm{H}_{0}$ & 0.011 & $\mathrm{H}_{1}$ & 0.000 & $\mathrm{H}_{1}$ \\
\hline 36 & 0.391 & $\mathrm{H}_{0}$ & 0.536 & $\mathrm{H}_{0}$ & 0.000 & $\mathrm{H}_{1}$ & 0.000 & $\mathrm{H}_{1}$ \\
\hline
\end{tabular}

Levene/Sig. Si Sig $\leq 0.05$ assumes unequal variances; $\mathrm{Sig}>0.05 \mathrm{SI}$ assumes equal variances.

The Levene's inferential analysis and $t$-test of the study dimensions revealed the following results (Table 9).

Table 9. Levene's inferential and $t$-analysis of the items of the 4 dimensions.

\begin{tabular}{|c|c|c|c|c|c|c|}
\hline Items & $\begin{array}{c}\text { Gender } \\
\text { Sigle }\end{array}$ & Sig.Bil.t & $\begin{array}{c}\text { R/U } \\
\text { Sig.Lev. }\end{array}$ & Sig.Bil.t & $\begin{array}{c}\text { Tit. } \\
\text { Sig.Lev. }\end{array}$ & Sig.Bil.t \\
\hline 20 & 0.889 & 0.505 & 0.162 & 0.033 & 0.024 & 0.026 \\
\hline 21 & 0.161 & 0.789 & 0.383 & 0.000 & 0.137 & 0.005 \\
\hline 22 & 0.865 & 0.049 & 0.000 & 0.027 & 0.770 & 0.002 \\
\hline 23 & 0.302 & 0.091 & 0.160 & 0.365 & 0.771 & 0.001 \\
\hline 24 & 0.882 & 0.781 & 0.008 & 0.317 & 0.033 & 0.058 \\
\hline 25 & 0.545 & 0.876 & 0.957 & 0.299 & 0.866 & 0.000 \\
\hline 26 & 0.005 & 0.287 & 0.342 & 0.204 & 0.000 & 0.000 \\
\hline 27 & 0.002 & 0.046 & 0.000 & 0.027 & 0.739 & 0.068 \\
\hline 28 & 0.810 & 0.158 & 0.453 & 0.011 & 0.582 & 0.902 \\
\hline 29 & 0.017 & 0.350 & 0.817 & 0.061 & 0.358 & 0.026 \\
\hline 30 & 0.852 & 0.007 & 0.953 & 0.404 & 0.271 & 0.004 \\
\hline 31 & 0.686 & 0.067 & 0.531 & 0.003 & 0.528 & 0.000 \\
\hline 32 & 0.749 & 0.029 & 0.145 & 0.054 & 0.000 & 0.000 \\
\hline 33 & 0.306 & 0.372 & 0.847 & 0.319 & 0.000 & 0.000 \\
\hline 34 & 0.612 & 0.733 & 0.385 & 0.017 & 0.040 & 0.000 \\
\hline 35 & 0.505 & 0.536 & 0.075 & 0.021 & 0.000 & 0.000 \\
\hline 36 & 0.014 & 0.076 & 0.453 & 0.062 & 0.033 & 0.002 \\
\hline
\end{tabular}

Levene/Sig. Si Sig $\leq 0.05$ assumes unequal variances; $\mathrm{Sig}>0.05 \mathrm{SI}$ assumes equal variances. Test $\mathrm{t} / \mathrm{Sig}$. Bilat. $\leq 0.05 \mathrm{H}_{1}$; Sig. Bilat. $>0.05 \mathrm{H}_{0}$.

For the gender factor, according to Levene's test, only differences in items 26, 27, 29 and 36 were significant. According to $t$, significance was found in 22, 27, 30 and 32. In the rural/urban factor, they reflected significance according to Levene: 22, 24 and 27. Likewise, $t: 22,27,28,31,34$ and 35 . In relation to the tenure factor, significance according to Levene's test was found in items 20,24,26,32,33,34, 35 and 36. Additionally, according to the bilateral significance $t$, all were significant except items 24,27 and 28 . 


\section{Discussion and Conclusions}

Teacher training remains one of the main essential pedagogical elements for the improvement of quality and inclusion in the education system. Our study suggests that it is essential to improve the ongoing training of teachers in educational inclusion and attention to diversity. Additionally, this applies to all teachers, especially non-specialist teachers who must also work in an unavoidable way for inclusive and quality education.

At a time when an interesting debate is taking place in Spain on how to configure the mechanisms of attention to diversity based on legislative and pedagogical approaches to inclusivity, not without controversy and conflicts of all kinds (social, political, ethical, moral, etc.), it is appropriate to note the firm commitment to models of teacher self-training in inclusive education $[30,31]$. Moreover, it is not a question of creating or investing more resources, but rather of reorienting existing resources and giving a more prominent role to guidance professionals and to the agents who form part of the guidance and diversity care teams in schools. In this sense, our study coincides with other studies $[32,33]$ which confirm the relevance of actively promoting other forms and methods of inclusive pedagogical training, especially through the promotion of greater flexibility and personalization in their attention to the diversity of students with SEN, and, in turn, a greater commitment to inclusive teaching strategies such as co-teaching and the participation of support and therapeutic pedagogy teachers in mainstream classrooms [34,35].

It is not, in any case, a question of strengthening a model of "expertism" or of inhibiting teachers' work and responsibility in specialist professionals, but of incorporating the "funds of knowledge" of all teachers in a cooperative, supportive way, open to public scrutiny and continuous improvement [36]. Obviously, from our point of view, this more inclusive pedagogical outlook is sponsored by teachers' self-criticism, not only of the education system, but also of their own degree of training and practical experience in improving care and personalizing educational responses. We agree with the work of [37], in that selfevaluation must form part of a key reflective dimension in the establishment of training proposals in inclusive education to improve the quality of attention to diversity, especially in times of enormous complexity such as those we are currently experiencing due to COVID-19. The current social and educational scenario has changed, and so must the training models, which must respond in a more adjusted, contextualized and situational way to the demands and training needs of the teachers themselves according to their professional reality.

Regarding guidance tools and teaching resources, the results of the present study coincide with similar research in which a predisposition to include resources and materials as essential elements for the implementation of effective and innovative strategies in inclusive teaching practice can be seen $[38,39]$. From the point of view of personal resources, it should be noted that the majority of teachers consider that both didactic and human resources should be significantly increased in order to improve the quality of attention to diversity and educational inclusion.

In the case of extracurricular and complementary activities, it is essential to clearly increase the visibility and participation of students with SEN in order to create an increasingly inclusive, cooperative, and supportive educational climate [40]. Thus, inclusive education requires opening up to the community all kinds of activities, initiatives, resources and participatory processes, among which the need to promote the culture of diversity in all dimensions and facets of school life is made visible [24]. The results show the need to increase the visibility and participation of children and young people with SEN in extracurricular and complementary activities. The trend towards a certain sensitivity towards the participation of these pupils under equal conditions is positive, although it should be stressed that there is still a long way to go given the scarcity in number and presence of pupils with disabilities in these activities.

We must mention the cooperative and supportive nature that can be constructively addressed in these extracurricular and complementary activities. Without prejudice to the importance of the recreational component, we must not forget that it is essential to listen to 
the voice of the students themselves and their families in order to undertake a broad offer that responds in an inclusive manner to this first-rate pedagogical and social aspiration. Enjoying learning must be at the service of all children, without exception.

Training in educational inclusion should not only be essential for specialist and support teachers, but also for all teachers in general. In this sense, support teachers together with classroom teachers can jointly establish a systematic, operational, and planned accompaniment within the regular classroom that leads to emerging models of co-teaching [15]. This implies significant changes in teaching and has implications for the adoption of new habits and routines and, therefore, progress towards the transformation of mentalities within educational communities.

In summary, the results show progress in teachers' perception of the need to promote substantial improvements in terms of a clear and applied pedagogical direction for the construction of a more inclusive education system. However, didactic and methodological training should continue to be strengthened, as should the development of experimentation and educational innovation in the field of inclusion and attention to diversity.

This study has some limitations that should be taken into account in the design of future research. Firstly, the data obtained were based exclusively on teachers, although it would be useful to have the views of families and other stakeholders in order to compare perceptions of inclusive education in school practice. Secondly, it would be useful to have an external framework for assessing inclusive education competences, e.g., observational data and self-assessments of participating teachers. Future studies should explore further the analysis of new evidence of change in educational practices, the participation of families and students with SEN in extracurricular activities (sports, music, art, drama, etc.), as well as the impact of teacher training proposals that move towards more innovative methodologies that foster co-operation.

Finally, it is necessary to focus attention on the type of lifelong learning in inclusive education, its orientation, and real impact on school practice, because it is a relevant key to analysis in the projection and strengthening of inclusive educational measures. It is also essential to reinforce psycho-pedagogical guidance actions on inclusion, as well as the optimization of didactic means and resources so that teachers can update and revitalize their teaching practices.

Author Contributions: Conceptualization, J.J.L.-O.; methodology, F.V.L.; software, F.V.L.; validation, F.V.L.; formal analysis, A.M.E.; investigation, J.J.L.-O.; resources, M.C.L.-B.; data curation, M.C.L.-B. and F.V.L.; writing-original draft preparation, J.J.L.-O. and M.C.L.-B.; writing-review and editing, J.J.L.-O.; visualization, A.M.E.; supervision, J.J.L.-O. and A.M.E.; project administration, J.J.L.-O.; funding acquisition, A.M.E. All authors have read and agreed to the published version of the manuscript.

Funding: This work arose from the R+D+I Research Project entitled "Evaluation of the response to students with Specific Educational Support Needs associated with disability in Compulsory Education: Current situation and proposal for improvement" (EDU2016-75574-P), of the Spanish Ministry of Economy, Industry and Competitiveness, with ERDF funds of the European Union.

Institutional Review Board Statement: The study was conducted according to the guidelines of the Declaration of Helsinki, and approved by the Institutional Review Board (or Bioethics Committee) of the University of Almeria (Ref. UALBIO 2019/039), which was demanded for the research EDU2016-75574-P.

Informed Consent Statement: Informed consent was obtained from all subjects involved in the study.

Data Availability Statement: Research data are currently available on the website, while the ministerial repository publishes the research data.

Conflicts of Interest: The authors declare no conflict of interest. 


\section{References}

1. Pérez Pérez, C.; López Francés, I. Las competencias del profesorado ante la educación inclusiva: Retos del futuro inmediato. Edetania 2017, 51, 69-82.

2. Mundial, B. Informe sobre el Desarrollo Mundial. In Aprender Para Hacer Realidad la Promesa de la Educación, Cuadernillo del "Panorama General"; Grupo Banco Mundial: Washington, DC, USA, 2018; pp. 1-40.

3. Carballo Lado, P. Formación del Profesorado para la Inclusión: A Propósito de Una visita de Estudio de un Grupo de Expertos de la Agencia Europea para el Desarrollo de la Educación del Alumnado con Necesidades Educativas Especiales. 2017. Available online: http://repositoriocdpd.net:8080/bitstream/handle/123456789/1924/Art_CarballoLadoP_ Formaciondelprofesorado_2011.pdf?sequence=1 (accessed on 22 January 2021).

4. Llorent García, V.J.; López Azuaga, R. Demandas de la Formación del Profesorado. El desarrollo de la educación inclusiva en la Educación Secundaria Obligatoria. REIFOP 2012, 15, 27-34.

5. García, P.A.R. Investigar las experiencias en lo escolar: Voces y cuerpos que desde la diversidad interpelan la educación contemporánea. Plumilla Educ. 2014, 14, 73-84. [CrossRef]

6. Alcaraz, S.; Arnaiz, P. La Escolarización del Alumnado con Necesidades Educativas Especiales en España: Un estudio longitudinal. Rev. Colomb. Educ. 2020, 299-320. [CrossRef]

7. Heyder, A.; Südkamp, A.; Steinmayr, R. How are teachers' attitudes toward inclusion related to the social-emotional school experiences of students with and without special educational needs? Learn. Individ. Differ. 2020, 77, 101776. [CrossRef]

8. Marouli, C. Sustainability Education for the Future? Challenges and Implications for Education and Pedagogy in the 21st Century. Sustainability 2021, 13, 2901. [CrossRef]

9. Garbanzo-Vargas, G.M. Desarrollo organizacional y los procesos de cambio en las instituciones educativas, un reto de la gestión de la educación. Rev. Educ. 2016, 40, 67-87. [CrossRef]

10. Camacho Prats, A. La arquitectura escolar: Estudio de percepciones. RIEJS 2017, 6, 31-56. [CrossRef]

11. Casserly, A.M.; Padden, A. Teachers' views of co-teaching approaches in addressing pupils with special educational needs (SEN) in multi-grade classrooms. Eur. J. Spec. Needs Educ. 2018, 33, 555-571. [CrossRef]

12. Carmona, C.E. Educación inclusiva. Un paradigma Transformador. Pedagogías de la inclusión. Forum Aragón 2017, $22,28-31$.

13. Moya, E.C. Hacia una educación inclusiva para todos. Nuevas contribuciones. Rev. Curríc. Form. Profesor. 2019, $23,1-9$.

14. Sealy, P. Preservice teachers' beliefs of competence with teaching socially sensitive issues. Psychol. Res. 2019, 9, 66-80.

15. Sandoval, M.; Muñoz, Y.; Márquez, C. Supporting schools in their journey to inclusive education: Review of guides and tools. Support Learn. 2021, 36, 20-42. [CrossRef]

16. Bronikowski, M.; Krzemińska, I.L.; Kantanista, A.; Bronikowska, M.; Szczepanowska, E.; Morina, B. Comparative study on self-assessment of teaching competencies of PE student teachers from Poland and Kosovo. Balt. J. Sport Health Sci. 2013, 11-20. [CrossRef]

17. Akpan, J.P.; Beard, L.A. Using Constructivist Teaching Strategies to Enhance Academic Outcomes of Students with Special Needs. Univ. J. Educ. Res. 2016, 4, 392-398. [CrossRef]

18. Cansino, J.A. Un nuevo paradigma para un futuro más saludable y con valores-Deporte Inclusivo, Actividad Física Inclusiva y Educación Física Inclusiva. Rev. Educ. Inclusiva 2017, 69-86.

19. Ascione, A.; Di Palma, D.; Napolitano, S. Social inclusion and education through sport and technology. Sport Sci. 2018, 11, 52-56.

20. Barber, W. Inclusive and accessible physical education: Rethink ingability and disability in pre-service teacher education. Sport Educ. Soc. 2018, 23, 520-532. [CrossRef]

21. Kristén, L.; Klingvall, B.; Ring, M. Theco-developmentof inclusive tools in physical education for pupils with and without disabilities. Sport Soc. 2020, 1-17. [CrossRef]

22. Pocock, T.; Miyahara, M. Inclusion of students with disability in physical education: A qualitative meta-analysis. Int. J. Incl. Educ. 2018, 22, 751-766. [CrossRef]

23. Walkup-Amos, T. Creating Inclusive Music Classrooms Through Peer-Assisted Learning Strategies. Teach. Except. Child. 2020, 52, 138-146. [CrossRef]

24. Calvo, M.; Verdugo, M.Á.; Amor, A.M. La participación familiar es un requisito imprescindible para una escuela inclusiva. Rev. Latinoam. Educ. Incl. 2016, 10, 99-113. [CrossRef]

25. Pascual, G.L.; Rodríguez, C.C. La inclusión socio-educativa de niños y jóvenes con diversidad funcional: Perspectiva de las familias. Rev. Educ. Incl. 2018, 11, 83-98.

26. Williamson, R.L.; Jasper, A.; Smith, C.; Novak, J.; Hunter, W.; Casey, L. Re-examining Evidence Based Practice in Special Education: A discussion. J. Int. Spec. Needs Educ. 2019, 22, 54-65. [CrossRef]

27. Observatorio Estatal de la Discapacidad. Alumnado con Discapacidad y Educación Inclusiva en España. Fase 1: La Educación Inclusiva en España. Marco Normativo y Políticas Públicas. Observatorio Estatal de la Discapacidad. 2018. Available online: https: / / www.observatoriodeladiscapacidad.info (accessed on 16 February 2021).

28. Fernández-Batanero, J.M.; Cabero, J.; López, E. Knowledge and degree of training of primary education teachers in relation to ICT taught to students with disabilities. Br. J. Educ. Technol. 2019, 50, 1961-1978. [CrossRef]

29. IBM Corp. IBM SPSS Statistics para Windows, Versión 25.0; IBM Corp: New York, NY, USA, 2017.

30. Mayo, M.E.; de la Iglesia, J.C.F.; Roget, F. La atención a la diversidad en el aula: Dificultades y necesidades del profesorado de educación secundaria y universidad. Context. Educ. 2020, 25, 257-274. [CrossRef] 
31. Toledo, P.; Llorente, M.C. Formación inicial del profesorado en el uso de Tecnologías de la Información y la Comunicación (TIC) para la educación del discapacitado. Digit. Educ. Rev. 2016, 30, 123-134.

32. Rappoport, S.; Sandoval, M.; Simón, C.; Echeita, G. Comprendiendo los sistemas de apoyo para la inclusión: Tres experiencias inspiradoras. Cult. Educ. 2019, 31, 135-151. [CrossRef]

33. Sandoval, M.; Simón, C.; Echeita, G. A critical review of education support practices in Spain. Eur. J. Spec. Needs Educ. 2019, 34, 441-454. [CrossRef]

34. Arnáiz, P.; Escarbajal, A.; Caballero, C. El impacto del contexto escolar en la inclusión educativa. Rev. Educ. Incl. 2017, 10, 195-210.

35. Sandoval, M.; Márquez, C.; Simón, C.; Echeita, G. El desempeño profesional del profesorado de apoyo y sus aportaciones al desarrollo de una educación inclusiva. Fac. Educ. Hum. Campus Melilla 2019, 49, 251-266. [CrossRef]

36. Zhang-Yu, C.; García-Díaz, S.; García-Romero, D.; Lalueza, J.L. Funds of identity and self-exploration through artistic creation: Addressing the voices of youth. Mind Cult. Act. 2020, 1-14. [CrossRef]

37. Arnaiz, P.; Martínez, M. Centros educativos que se autoevalúan y reflexionan sobre sus resultados para mejorar la atención a la diversidad. REOP 2018, 29, 74-90. [CrossRef]

38. Martí, J.A.T.; Sales, A.; Moliner, O.; Ribés, A.S.; Gil, A.B. Hacia una escuela incluida en su territorio: Análisis de una práctica comunitaria. Estud. Propues. Soc. 2018, 53, 99-116.

39. Sales, A.; Moliner, O.; Sanahuja, A.; Benet, A.; Escobedo, P. La Escuela Incluida: Vinculación del currículum al territorio a través de procesos de investigación-acción participativa. In Inclusión y Mejora Educativa; Torrego, J.C., Rayón, L., Muñoz, Y., Gómez, P., Eds.; Servicio de Publicaciones Universidad de Alcalá: Alcalá, Spain, 2017; pp. 643-648.

40. Sanahuja, A.; Moliner, O.; Moliner-Miravet, L. Organización del aula inclusiva: Cómo diferenciar las estructuras para lograr prácticas educativas más efectivas? Rev. Complut. Educ. 2020, 31, 497-506. [CrossRef] 